\title{
DOI: 10.7596/taksad.v9i2.2636
}

Citation: Chaiuk, T. A., \& Dunaievska, O. V. (2020). Producing the Fear Culture in Media: An Examination on Coronavirus Discourse. Journal of History Culture and Art Research, 9(2), 184-194. doi:http://dx.doi.org/10.7596/taksad.v9i2.2636

\section{Producing the Fear Culture in Media: An Examination on Coronavirus Discourse}

\author{
Tetyana A. Chaiuk ${ }^{1}$, Olha V. Dunaievska ${ }^{2}$
}

\begin{abstract}
Fear culture has become a central perspective of viewing life in Western societies where the feeling of vulnerability and insecurity has increased over the past few decades. Sociological studies on the culture of fear provide the theoretical background for understanding how the media coverage of the coronavirus outbreak helps to cultivate the audience's anxiety. The purpose of this article is to examine how the COVID-19 outbreak was presented in British newspapers and what language means were used to breed the anticipation of danger even before the first lethal case was registered in the UK, that is from January 1 to March 5, 2020. To identify the verbal means employed by newspapers to present the coronavirus as the ultimate threat and thus to cultivate a fear culture among their readers, Critical Discourse Analysis (CDA) is chosen as the main method of the research, since it looks into how language means are used in media texts to produce an intended effect on audiences. The study reveals that the newspapers' editorials, headings, and articles of that period framed the coronavirus pandemic in terms of fear-mongering by dramatizing reports on the epidemic in China, by metaphorically presenting the coronavirus as deadly living thing approaching Great Britain and finally hitting the country like a tsunami, by repeatedly emphasizing the globality of the pandemic and inadequacy of the government's measure to curb the disease.
\end{abstract}

Keywords: Coronavirus, Fear culture, Critical Discourse Analysis, British newspapers, Metaphor.

\footnotetext{
1 Ph.D. in Philology, Associate Professor, Taras Shevchenko National University of Kyiv, Faculty of Law, Department of Foreign Languages, Ukraine. E-mail: chajuk.t@gmail.com

2 Ph.D. in Philology, Associate Professor, Taras Shevchenko National University of Kyiv, Faculty of Law, Department of Foreign Languages, Ukraine. E-mail: o.dunayevska@gmail.com
} 


\section{Introduction}

Though people in Western societies are enjoying good health and longevity due to advancements in medical science and control of infectious diseases, they feel increasingly vulnerable to illnesses and worried about their health. Buckingham (2008) calls this phenomenon a "health paradox", while Burgess (2008) refers to this as the "worried well". Thus, fear is no longer a response to a threat, but "a cultural idiom" (Furedi, 2006, p.vii), which justifies the term 'culture of fear' that Furedi, along with Glassner (1999), uses to talk about modern societies. Fear, therefore, may be conceptualized nowadays as a social phenomenon (Furedi, 2007, p.2).

It is argued that fear is a "product of social construction": that is, it is purposefully cultivated in a society and is then used by manipulators to get some benefit (Altheide, 2002, p.24; also see Glassner, 1999, p.xxiii). In the modern public space, to obtain the representation of reality, people turn to mass media (Matsaganis \& Payne, 2005, p.385), so we 'play' with fear and "more of our "play worlds" come from the mass media" (Altheide, 2009, p.48) whose powerful influence shapes the very foundation of people's perception (Mazzoleni \& Schultz, 1999, p.248). As a result, scientists speak of a shift from a "fearsome life towards a life with fearsome media" where "fear is powerfully communicated and disseminated through the media" (Fischer \& Bonss, 2013, p.10; see also Grupp, 2003, p.43). In other words, reliance on first-hand, direct individual experience has been superseded by reliance on information obtained from the media that prioritize negative, extraordinary, sensational news.

Media tell us what to think about and also affect what we think of a particular topic (Daddow, 2012; Khalid, 2013; de Freitas, 2020). This means that media coverage determines the topics of public discourse by making media agenda central to people's everyday conversations and arousing certain emotions, fear being one of them (de Freitas, 2020). For example, extensive (sometimes inadequately excessive) coverage of an event turns the public anxious or just too much concerned. Besides extensive media coverage, the list of techniques that help the media shape society's perception of risk includes the volume of information provided, the way in which the risk is framed as well as the symbols and metaphors used to describe and characterize the risk (Furedi, 2002, pp.52-53).

Cultivation of the "fear culture" is a complex phenomenon that should not be oversimplified, yet it is tabloids that are often mentioned as one of 'fear-generators': they fuel the existing fears (Altheide, 2002; Furedi, 2006) and use scares to attract readers (Glassner, 1999, p.xxiii). Researchers point out a peculiar language employed by mass media. Tabloids, for example, provide their readers with a distinct sensationalist, emotive linguistic compendium with highly influential range of language use (Conboy, 2006, p.15) that underpins their distinctive use of popular idiom (Conboy, 2006, pp.1213).

The role of media in covering public health crises (e.g., SARS and Ebola epidemics) has been analysed by a number of scholars who have examined a range of features that influence media coverage. These are proximity to the virus epicentre and local cultures (Tzogopoulos, 2020). Some scholars also add national and political contexts to this list (Kapiriri \& Ross, 2018).

Over the last few decades, fears of contagious diseases, emerging and re-emerging globally, have been escalated by several epidemics (SARS, Zika, Ebola to name just a few) and medical issues have become common 'scares' in the media (Glassner, 1999; Furedi, 2006; Burgess, 2008). The diseases have proved to be unpredictable, bring about uncertain, varying risks and narratives in different contexts (Scoones, 2010). Most of the epidemics had a high death rate, annual seasonal influenza being the champion with estimated 3 to 5 million severe cases and about 290,000 to 650,000 deaths every year (WHO, 6 November 2018). 
The topicality of the research lies in that it aims at clearing out why, though the feeling of fear is a normal human reaction to uncertainties, the rate of uncertainty and anxiety about the coronavirus seems much higher than with any other epidemic.

The purpose of the research lies in that it attempts to identify the means that have helped the media present the coronavirus outbreak as the ultimate threat to humanity in general and every individual in particular, breeding fear culture on the global scale and affecting everyday practices and discourse of billions of people. The object of study is to analyse strategies used by British newspapers to cultivate fear among the readers, while the subject is language means employed to breed fear and anxiety among the readers. The research material consists of texts ( 78 articles, 147 headlines) that appeared in British newspapers (The Guardian, The Independent, The Daily Express, The Daily Mail, The Sun, The Telegraph and others) from January 1 to March 5, 2020.

\section{Methodology and background}

The research is based on the concept of discourse interpreted as "practices that systematically form the objects of which they speak" (Foucault, 1982, p.49). Discourse is understood within the constructivist framework, i.e. discourse constitutes or adds to the construction of reality. Foucault states that "in every society, the production of discourse is at once controlled, selected, organized and redistributed by a certain number of procedures whose role is to ward off its powers and dangers, to gain mastery over its chance event, to evade its ponderous, formidable materiality" (1984, p.52). For Fairclough, discourse is "language use, whether speech or writing, seen as a type of social practice" (1992, p.28) where language is not neutral. As a result, all texts are seen as "critical sites for the negotiation of power and ideology" (Burns \& Coffin, 2001, p.138) where language is used to construct and disseminate a social representation of reality.

Critical Discourse Analysis (CDA) has been chosen as the research method, since it looks into how language means are used in media texts in order to influence the audience and get the intended reaction (Van Dijk, 2001; Fairclough, 1992). CDA provides a researcher with the inventory to consider how the media hone their texts to represent and process the public debate. This approach focuses primarily on vocabulary, selectivity and representation: each language element is a complicated and sensitive instrument played by a language user. Thus, the perception and understanding created in the recipient depend on how the addresser uses this sensitive tool. CDA assumes that, being frequently used in public discourse, words may become 'meaningfully joined' and develop shared connotations. These connotations, then, spread over all the contexts these words appear in and turn these words into self-explanatory and emotionally self-sufficient signs. This is how words start to imply fear (cf., gang, drugs) (Altheide, 2003).

It is important to note that CDA requires considering media texts (articles in our case) and events in context, since news narratives do not exist in isolation and are effectively written into the continuum of issues, events and beliefs that surround them (Bednarek, 2006). Another important linguistically valid feature a researcher should be mindful of is modality, i.e. "ways in which language is used to encode meanings such as degrees of certainty and commitment, or alternatively vagueness and lack of commitment, personal beliefs versus generally accepted or taken for granted knowledge" (Stubbs, 1996, p.6).

CDA proponents assume that newspaper discourse creates 'shared values' and aims at forming a relationship on the basis of the reader's assimilation of interests, social expectations and assumptions (Van Dijk, 1988, p.19; Busa, 2013, p.25). A set of news values may be selected in order to mould and perpetuate an opinion as well as to establish norms that are accepted by readership uncritically (Bednarek \& Caple, 2012, p.23).

From the point of view of the Foucauldian framework, mass media shape our social world and contribute to changing everyday life routines, social expectations and public discourse by promoting 
the culture of fear. Consequently, the feeling of fear begins to permeate discourse when it ceases to be associated with only one referent and develops a larger scope (Altheide, 2002, p.3). CDA is unavoidable to study language choices made by the British press in order to impose their agenda on their readers, to conceptualize reality as a threat and to 'shape' the readers' idea of the 'common sense'.

\section{Results and Discussion}

On December 31, 2019, the World Health Organization (WHO) was informed of a pneumonia of unknown cause, detected in the Huanan Seafood market in Hubei province, China. 10 days later, the virus was identified as novel coronavirus developed with reference to other coronaviruses, such as SARS and MERS, with the estimated fatality rate case $2 \%$ and which became 3.4 on March 3. The outbreak received extensive attention of international media including British newspapers that started to report fearful news from China emphasizing repeatedly that the virus might reach Europe and framing the disease as a dire threat to Europe and Britain. Two weeks later the WHO announced that the novel coronavirus (COVID-19) had spread out of China with cases in the Republic of Korea, Japan, Thailand and Singapore. When on January 24 France officially notified three confirmed COVID-19 cases, the media tone of alarm started to get heightened with threats. The outbreak was declared Public Health Emergency of International Concern on January 30, 2020 (World Health Organization, 2020), and later, on March 11, the WHO declared COVID-19 a global pandemic.

The intensive media coverage of the coronavirus pandemic is unprecedented: no other disease has become the core of vigilance of the media dominating the news cycle. The way the epidemic has been covered by newspapers is by itself a manifestation of the culture of fear inherent in the British society. Headlines of newspaper front pages were largely centred on fear itself or reacted to it. A Time Magazine study has shown a huge gap of English-language print news covering the coronavirus outbreak during the first month compared to the same time period for the Ebola epidemic in 2018:

Throughout January 2020, the first full month of the outbreak, more than 41,000 English-language print news articles mentioned the word 'coronavirus', and almost 19,000 included it in their headlines... By contrast, only about 1,800 English-language print news articles published in August 2018, the first month of the DRC outbreak, mentioned 'Ebola', and only about 700 headlines mentioned the disease. (Ducharme, 2020)

The British press started fear-mongering by using sensational language in its reports to describe the ongoing disease in China. The media emphasized the possibility of the virus to reach Europe and, consequently, framed the disease as a keen threat. According to Altheide, in order to construct the discourse of fear, one turns to emotive means that produce a dramatizing effect on the audience (Altheide, 2003). This is what is done in The Telegraph's description of events in Wuhan, the epicentre of the 'deadly coronavirus':

(1) Mask-wearing patients fainting in the street. Hundreds of fearful citizens lining cheek by jowl, at risk of infecting each other, in narrow hospital corridors as they wait to be treated by doctors in forbidding white hazmat suits. A fraught medic screaming in anguish in a break-room (Smith \& Newey, 2020).

The two sentences are packed with fear-inducing vocabulary that produces a dramatic effect similar to that of a scene from a horror movie: the suffocating lack of space (lining cheek by jowl, narrow corridors), crowds (hundreds of citizens) and illness (mask-wearing, fainting, infecting, hospital, doctors, fraught, anguish).

It is noteworthy that even before the first death case in the United Kingdom, namely before March 5, the coronavirus received much attention and was framed as a threat to Brits' everyday life: headlines in large font contained catchy alarmist phrases to ceaselessly describe the virus as "deadly 
virus", "killing" and "infecting", "out of control" and "highly contagious", the virus that had reduced "the Hubei province to a ghost town" (Wooller, 2020). Picturing the "never-before-seen killer" virus (Matthews, Blanchard \& Martin, 2020) as a treacherous enemy with "many victims" who "have mild, cold-like symptoms and don't realise they have the infection" (Matthews et al., 2020), the UK press used medical vocabulary (e.g., immunity, pandemic, epidemic, infection, patient, outbreak) alongside with the vocabulary that transferred the epidemic narratives into a military discourse by developing the metaphors of war and fight (e.g., a battle, to surround, to defeat, to combat, to hit, to fight, to beat, onslaught).

Another feature of newspaper coverage that evokes war associations is the permanent publication of the world map where the readers could see how the virus travelled around the globe: the map indicated the countries affected by the virus, provided with the data on the number of deaths as if it were war dispatches, reported the number of schools closed, etc. (see, for example, images in (Keogh, Borland, Payne \& Robinson, 2020)). This layout of information resembles news from the theatre of operations that informs of the body count and the number of injured.

As a result, the metaphorical language and visuals combined with the term "public health emergency" transform real life into a script of a disaster movie (see, for example (Stewart, 2020)). This coverage intensified the atmosphere of fear and boosted the general feeling of anxiety and insecurity among British readers.

Throughout January and February, 2020, the newspapers wrote about the virus as if it were a monstrous living thing who had come to life in the faraway part of the world but was gradually creeping on, covering distances, conquering countries. This is the message delivered by reporters from Daily Star and the Daily Mail:

(2) ...the virus has broken out of China... the disease, which has already killed 17 in China and has affected up to 1,700 people, could already have arrived in the UK (Moran, 2020).

(3) ...the virus crisis tightened its grip on the UK today; coronavirus could now gain a foothold in Britain (Keogh, Borland, Payne, \& Robinson, 2020).

Here, the verbs to break out, to kill, to arrive imply intentionality and purposefulness of the virus' actions, whereas the idioms to tighten one's grip and to gain a foothold picture the virus as a limbed monster.

Scholars believe that national and global responses to epidemics are inherently political: "The experts selected for consultation, the evidence used to inform response pathways, and narratives of blame, vulnerability, and responsibility are politically driven" (Kapiriri \& Ross, 2020, p.1). In their coronavirus coverage, The Telegraph quotes "experts" making a gruesome prediction and uses in one sentence terrifying clichés "killer virus" and "death toll rises", both evoking the DEATH concept: 2020).

(4) Killer virus 'could reach the UK' as death toll rises, warn experts (Knapton,

The Telegraph keeps stoking the Brits' fears by recalling one of the most lethal pandemics in human history and reminds that its death rate is the same as that of the coronavirus:

(5) ...the fatality rate on par with the 1918 Spanish Flu epidemic, which wiped out 50 million people globally (Knapton, 2020).

The density of negatively connoted and fear-inducing vocabulary (fatality rate, epidemic, wiped out) is combined with the figure (50 million) and the adverb globally, which legitimizes the words 
of another unnamed expert who believes that the 'killer' may as well be in their country: "one expert said he could not rule out that the virus is already in the UK" (Knapton, 2020)

The Sun seconds in. The article is titled World War Flu, which sums up the frightening key features of the virus (i.e., globality, death/danger, disease). The newspaper states that "the virus, which has claimed 17 lives in China, could already have spread to Britain" (Wooller, McDermott, \& Sales, 2020). Taking into account the population of the Chinese city, 17 deaths is not an impressive figure, but "perception of risk often has little to do with actual risk" (Furedi, 2006, p.23), especially when the alarmist language permeates every sentence of the article.

Boosting the anxiety, The Mail assigns globalization to be responsible for the hypothetical, at that time, the spread of the disease: "Globalization has made the nightmare of pandemics more likely, and harder to control" (Matthews, Blanchard \& Martin, 2020). The threatening situation is exacerbated by the "complacent" government whom the newspaper urges to step up checks in the world where "everyone could be a potential transmitter or a victim" (Matthews et al, 2020).

Another paper says that ministers deserve a "rap on the knuckles" for failing to introduce temperature tests for those coming from infected areas (Duff, 2020). As a result, "the UK is on high alert with monitoring of flights arriving in Britain" (Moran, 2020), and, at last, "ministers have ordered a "clampdown" on flights from Wuhan, the city at the centre of the outbreak" (Wooller, McDermott \& Sales, 2020). However, The Telegraph expresses doubts about the effect of these measures by calling borders "too porous", which implies that they cannot stop the danger from leaking into the country. Therefore, the public is convinced that the virus is far from warded off:

(6) The deadly coronavirus outbreak in China could reach Britain because borders are too 'porous' to keep the infection out, experts have said (Knapton, 2020).

The anxiety and feeling of imminent danger generated by media increases after the first cases of the virus are reported in France on January 24. At the time, the British National Health Service officials start tests for potential patients that may have contracted the virus. Interestingly, the British press gives prominence to articles on the public fear rather than informative materials about the spread of the virus itself. The Times, for example, publishes the article titled China coronavirus: Growing fears over virus as tests begin in Britain (Smyth, Lloyd, Andrews, \& Puttick, 2020). Further in the article, the newspaper quotes Matt Hancock, the health secretary, who warns of "likely" cases of the "rapidly developing global outbreak in which more than 20 million people have been quarantined" (Smyth et al., 2020).

The audiences who have been exposed to 'fear climate' and perceive everyday life as always somewhat dangerous are more inclined to regard the coronavirus as a real threat and, thus, to accept easily the 'worst-case scenarios' forecast by media. These 'worst-case scenarios' are seen by many scholars as part of the fear culture. British newspapers enhanced the spread of scares by their repetitive predictions of the outbreak and anticipation of worse scenarios. The Daily Mirror, for example, says that the virus will be "impossible to contain here if it sweeps mainland Europe" (Bagot, 2020). Ministers are "considering a worst-case scenario that 50 million people here could catch the bug and it could kill 500,000 - mainly the elderly and those already unwell" (Bagot, 2020). This "could involve up to $80 \%$ of the population being infected" (Bagot, 2020). Thus, the newspapers elaborate on the worst-case scenario by providing the figures and specifying social groups that will be affected the most.

The Guardian gives a further dash of the approaching global threat by reporting that the outbreak "has accelerated across Europe with new cases in four countries and a rising death toll in Italy, which is struggling to contain the outbreak" (Mason \& Siddique, 2020). Thus, the danger becomes even more real for the UK as more European countries fall victims to the virus. The Daily Mail talks 
about "growing fears that the coronavirus could now gain a foothold in Britain because of the 100,000plus people travelling between the two countries every week" (Keogh, Borland, Payne \& Robinson, 2020).

Haunted by fear and repeatedly informed of the authorities' "desperate bid to delay the outbreak" (Bagot, 2020), British citizens are consistently pushed to two conclusions: the inevitability of a lockdown and emphasis on self-reliance. An article published on February 27 mentions stockpiling and stocking four times (stockpiling frenzy, stocking food) to describe the Brits' preparations for an uncertain future, e.g.

(7) ...yesterday spooked mums spoke of stockpiling medicines, food, nappies, water and pet food online. (Bagot, 2020)

When the coronavirus does arrive in the UK, the newspapers are quick to report that "experts who helped to fight the deadly SARS virus" accused the British authorities "of missing the "golden period' to curb the outbreak" (Matthews, Blanchard, \& Martin, 2020). Another newspaper writes that "officials give up stopping the disease and focus on delaying its inevitable onslaught" (Borland, Groves, \& Spencer, 2020). This statement was easy to believe in, because it actually declared that the expected 'worse scenario' had come true. The Daily Mail reporters add more fuel to the bonfire of fear:

(8) ...it's been alleged that those infected in China are freely roaming the streets (Matthews et al., 2020)

The atmosphere of insecurity, threat and anticipation of the worst is noticed and reported by the newspapers that remark on "panic buying in supermarkets and people travelling on public transport in makeshift masks" (Borland et al., 2020).

It is interesting how the press used modality in their texts along the 'certainty - uncertainty' scale. Above, we have seen the reporter hedging the statement with it has been alleged, which gives the reader food for thought rather than verified information.

The Sun was absolutely categorical in their initial statement (often a headline):

(9) Coronavirus is sure to become a deadly epidemic (THE SUN SAYS, 2020).

Yet, the newspaper was less categorical in its further claims when it wrote that the number of patients "looks certain to soar" (THE SUN SAYS, 2020). While is sure to express absolute certainty (just like the adjective inevitable that repeatedly appears as a modifier to the terms epidemic and pandemic), the phrase looks certain is far from being absolutely categorical and assertive because looks is a downtoner (cf., 'it looks certain' vs. 'it is certain': looks has a strong meaning of personal, i.e. subjective, assessment, while is presupposes unbiased objectivity).

It is remarkable how one may play down even the inevitability of the adjective inevitable. This is what we find in the following case:

(10) Ministers are now expected to escalate their response which would mean no longer trying to 'contain' the disease's seemingly inevitable spread (Borland, 2020).

The adverb seemingly, again, reduces the author's responsibility for the statement by adding a touch of personal opinion. A similar process is observed in another sentence that quotes an expert:

(11) Professor Whitty warned the virus was probably already spreading person-to-person in the UK and an epidemic was looking 'likely' (Borland, 2020). 
Here, the journalist uses several hedges: the modal word probably, the verb look and inverted commas with likely. The commas are intended to emphasize that this very word is Professor Whitty's personal opinion.

Another example of avoiding categorical statements is found in The Daily Telegraph's article titled "Pandemic funeral services could be streamed online to cut infections". The very title contains the modal verb could that presents the proposition as a possibility in future but not a fact. In the article, the journalist reduces the categorical meaning twice - with the modal verb and with the conditional sub-clause:

(12) Funerals of coronavirus victims could be transmitted to mourners over the internet to prevent the spread of the disease if it becomes a pandemic (Rayners, 2020).

It should be noted that could appears regularly in the publications of the sample.

Taking into account the January-February newspaper discourse, it came as no surprise when, on March 4, the Department of Health and Social Care of England reported that the number of coronavirus patients had jumped from 32 to 85 cases, the biggest daily increase recorded. Although at that time there was not even a single death case within the UK (the first death case of a 70-year-old woman with some other previous illnesses was confirmed on March 5), the acute sense of fear was skilfully planted and enhanced by the British press. On the very next day ( 5 March), the British papers published a scene from the Doom Day with the help of metaphorical language that sent the readers straight to the inevitable apocalypse: "the wave is coming" and "nothing can stop" it from "sweeping Britain" (Sheldrick \& Hall, 2020). What was pictured as a strong-limbed monstrous killer turned into a devastating tsunami with the help of the word wave. Just like with any tsunami, there will be "the point of no return".(Borland, Groves, \& Spencer, 2020): "things will soon get more serious" and there will be a need for "more draconian steps sooner rather than later" because (as it has been mentioned numerous times before) "the health service lacks the beds, staffing and resources" (THE SUN SAYS, 2020).

The Independent boosts the dramatic effect by publishing their reporter's first-hand experience in a hospital: it "was full and patients were waiting over 12 hours in A\&E for admission" (Lintern, 2020). The journalist reports a doctor's terrifyingly helpless comment that the chaos occurs "before we've even contemplated dealing with a single coronavirus case" (Lintern, 2020). The Independent goes further in spreading horror among the readers by saying that some victims won't be allowed to be hospitalized: the paper quotes the Chairwoman of Association of Critical Care Nurses who tells about the shortage of resources and the necessity to face the horrible reality:

(13) There simply aren't enough beds. We will need to make difficult decisions about which patients are admitted. The general public have a right to the truth (Lintern, 2020).

The passage from The Daily Telegraph may be considered the climax of fear-mongering. It brings together the two topics that are viewed as the most impressive for human psyche - death and disease - in the article titled Pandemic funeral services could be streamed online to cut infections. The density of the negatively connoted vocabulary is remarkable: here we find "funeral services", "crematoria", "mortuaries", "funerals", "mourners", "bereaved relatives", "cremations", "multiple graves" (all are slots of DEATH concept) as well as "pandemic", "infections", "coronavirus victims", "disease", "contracting the illness", "to infect" (slots of DISEASE concept). The article prepares the readers to face numerous deaths and the virus' horrendous fatality:

(14) ... crematoria might have to stay open 24 hours a day... to cope with up to $\underline{50,000 \text { extra }}$ deaths a week (Rayner, 2020). 


\section{Conclusion}

The fear connected to the coronavirus outbreak is related to the broader culture of fear and anxiety typical of modern Western societies. However, the COVID-19 epidemic had been given exceptional attention in the British press months before the virus came to the UK. As the study has revealed, the newspaper editorials, headlines and articles of the sample framed the epidemic in terms of fear-mongering: starting from January 1 , they gradually intensified the feeling of fear and anxiety by dramatically picturing the epidemic in faraway China until the first death case in Great Britain on March 5. To cultivate the premonition, the newspapers employed a range of strategies: they described the epidemic in the Chinese province as if it were a horror-movie script; they persistently used deathand war-related vocabulary and visuals, which, at first, pictured the virus as a vicious monstrous living thing from a distant part of the world and which later turned into a destructive tsunami hitting Britain; they kept on emphasizing the global scale of the epidemic, which implied that the UK would inevitably experience the onslaught of the disease; they kept on accusing the government of insufficient or belated measures taken to stop the pandemic and, by doing so, stoked the worst-case scenario expectations in their audience. The study shows an important role played by mass media as the main constructor of social reality (the media point out dangers, shape anticipations, and cultivate anxiety and fear in their audiences) whose main tool is language.

\section{References}

Altheide, D. L. (2003). Mass Media, Crime, and the Discourse of Fear. The Hedgehog Review. Retrieved from https://hedgehogreview.com/issues/fear-itself/articles/mass-media-crime-and-the-discourseof-fear

Altheide, D. L. (2009). Terror post 9/11 and the media. New York, Oxford: Peter Lang, Inc.

Altheide, D. L. (2002). Creating Fear, News and the Construction of Crisis. New York: Aldine De Gruyter.

Bagot, M. (2020, February 27). Nurses and paramedics will visit UK homes to perform coronavirus tests. The Mirror. Retrieved from https://www.mirror.co.uk/news/uk-news/coronavirus-home-tests-rolledout-21585534

Bednarek, M. (2006). Evaluation in Media Discourse. London: Continuum.

Bednarek, M., \& Caple, H. (2012). News discourse. London: Continuum International Publishing Group.

Borland, S., Groves, J., \& Spencer, B. (2020, March 5). The point of no return: Britain on the coronavirus brink as officials give up stopping the disease and focus on delaying its inevitable onslaught. The Daily Mail. Retrieved from https://www.dailymail.co.uk/news/article-8076267/The-point-no-returnBritain-coronavirus-brink-36-new-cases-total-soaring-87.html

Buckingham, A. (2008). Doing Better, Feeling Scared: Health Statistics and the Culture of Fear. In D. Wainwright (Ed.). A Sociology of Health (pp.19-37). London: SAGE.

Burgess, A. (2008). Health Scares and Risk Awareness. In D. Wainwright (Ed.). A Sociology of Health (pp.56-75). London: SAGE

Burns, A., \& Coffin, C. (eds.) (2001). Analysing English in a Global Context: A Reader. London: Routledge.

Busà, M. G. (2013). Introducing the language of the news. London: Routledge.

Conboy, M. (2006). Tabloid Britain: Constructing a Community Through Language. New York: Routledge.

Daddow, O. (2012). The UK media and Europe: from permissive consensus to destructive dissent. International Affairs, 88(6), 1219-1236. 
De Freitas, W. (2020). Coronavirus: how media coverage of epidemics often stokes fear and panic. The Conversation. Retrieved from https://theconversation.com/coronavirus-how-media-coverage-ofepidemics-often-stokes-fear-and-panic-131844

Ducharme, J. (2020). News coverage of coronavirus in 2020 is very different than it was for Ebola in 2018. The Times. Retrieved from https://time.com/5779872/coronavirus-ebola-news-coverage/

Duff, O. (2020, January 23). China coronavirus: Vigilance key to containing virus as medics will not know the destructive potential for weeks. The $i$. Retrieved from https://inews.co.uk/opinion/editor/chinacoronavirus-analysis-vigilance-key-destructive-potential-1374334

Fairclough, N. (1992). Discourse and Social Change. Cambridge: Polity Press.

Fischer, D., \& Bonss, W. (2013). The Induction of Fear by The Media. In Increasing Resilience in Surveillance Societies (pp.10-15). Edinburgh: The University of Edinburgh. Retrieved from http://irissproject.eu/wp-content/uploads/2013/04/Political-perspectives-of-surveillance-anddemocracy-report-D2.2-IRISS.pdf

Foucault, M. (1982). The Archaeology of Knowledge. New York, NY: Pantheon Books.

Foucault, M. (1984). The Order of Discourse. In R. Young (Ed.) Untying the text: A post-structuralist reader (pp.48-78). London: Routledge \& Kegan Paul Ltd.

Furedi, F. (2002). Culture of Fear. Risk-Taking and the Morality of Low Expectation. London, New York: Continuum.

Furedi, F. (2006). Culture of Fear. Risk-Taking and the Morality of Low Expectation (2 ${ }^{\text {nd }}$ Edn). London: Cassell.

Furedi, F. (2007). The only thing we have to fear is the 'culture of fear' itself. Retrieved from http://www.spiked-online.com/index.php?/site/article/3053/

Glassner, B. (1999). The culture of fear. New York: Basic Books.

Grupp, S. (2018). Political Implications of a Discourse of Fear: the Mass Mediated Discourse of Fear in the Aftermath of 9/11. In F. Furedi How Fear Works: Culture of Fear in the Twenty-First Century. London: Continuum.

Kapiriri, L., \& Ross, A. (2020). The Politics of Disease Epidemics: a Comparative Analysis of the SARS, Zika, and Ebola Outbreaks. Global Social Welfare, 7, 33-45. Retrieved from https://doi.org/10.1007/s40609-018-0123-y

Keogh, G., Borland, S., Payne, T., \& Robinson, M. (2020, February 27). Coronavirus threat to YOUR holiday: Millions of trips are at risk as BA cancels flights and fresh cases are reported across Europe from Norway to Greece and on every continent except Antarctica. The Daily Mail. Retrieved from https://www.dailymail.co.uk/news/article-8048853/Coronavirus-threat-holiday-Millions-trips-riskBA-cancels-flights.html

Khalid, P. (2013). Modality Analysis of the Newspaper Articles about the Scottish Ship RMS Queen Elizabeth. Academic Journal of Interdisciplinary Studies, 2(9), 458-461.

Knapton, S. (2020, January 22). Coronavirus spreads: Borders too 'porous' to keep disease out of Britain, warn experts. The Telegraph. Retrieved from https://www.telegraph.co.uk/science/2020/01/22/borders-porous-keep-coronavirus-britain-warnexperts/

Lintern, S. (2020, March 4). 'The public has a right to the truth': NHS staff speak out on coronavirus fears. The Independent. Retrieved from https://www.independent.co.uk/news/health/coronavirusnhs-deaths-test-positive-intensive-care-matt-hancock-a9376101.html

Mason, R., \& Siddique, H. (2020, February 26). Ministers preparing for potential big jump in coronavirus cases. The Guardian. Retrieved from https://www.theguardian.com/world/2020/feb/26/matthancock-clarifies-coronavirus-travel-advice-after-criticism 
Matsaganis, M., \& Payne, G. (2005). Agenda Setting in a Culture of Fear: The Lasting Effects of September 11 on American Politics and Journalism. American Behavioral Scientist, 49, 379- 392.

Matthews, S., Blanchard, S., \& Martin, H. (2020, January 24). 'We were told to ring NHS 111 if we feel ill... that's it!' Heathrow passengers arriving from coronavirus epicentre claim they were barely checked on landing - as death toll hits 17 and China QUARANTINES an entire city. The Daily Mail. Retrieved from https://www.dailymail.co.uk/health/article-7915845/Killer-Chinese-coronavirusprobably-way-Britain.html

Mazzoleni, G., \& Schultz W. (1999). "Mediatization” of Politics: A Challenge for Democracy? Political Communication, 16(3), 247-261.

Moran, M. (2020, January 23). Deadly coronavirus 'could already be in the UK' says medical expert. Daily Star. Retrieved from https://www.dailystar.co.uk/news/latest-news/deadly-coronavirus-couldalready-uk-21336004

Rayner, G. (2020, March 5). Pandemic funeral services could be streamed online to cut infections. The Daily Telegraph. Retrieved from https://www.telegraph.co.uk/news/2020/03/04/pandemic-funeralservices-could-streamed-online-cut-infections/

Scoones, I. (2010). Fighting the flu: risk, uncertainty and surveillance. In S.Dry, \& Leach, M. (Eds.) Epidemics: Science, Governance, and Social Justice (pp.137-163). London, Washington: Routledge.

Sheldrick, G., \& Hall, M. (2020, March 5). Coronavirus UK warning: 'Nothing can stop' virus sweeping Britain. The Express. Retrieved from https://www.express.co.uk/news/uk/1251053/Coronavirus-UKwarning-virus-latest-figures

Smith, N., \& Newey, S. (2020, January 26). Coronavirus: Fears rise of Chinese cover-up as 56 million in lockdown and hospitals overwhelmed. The Telegraph. Retrieved from https://www.telegraph.co.uk/news/2020/01/24/coronavirus-fears-rise-chinese-cover-up-40-millionlockdown/

Smyth, C., Lloyd, R., Andrews, K., \& Puttick, H. (2020, January 24). China coronavirus: Growing fears over virus as tests begin in Britain. The Times. Retrieved from https://www.thetimes.co.uk/edition/news/coronavirus-two-more-chinese-cities-quarantined-aswuhan-meat-market-blamed-b55pfwhzq

Stewart, H. (2020). The language of fear used in media reports about the coronavirus is stoking prejudice. Euronews. Retrieved from https://www.euronews.com/2020/02/10/the-language-of-fearused-in-media-reports-about-the-coronavirus-is-stoking-prejudice-view

Stubbs, M. (1996). Towards a Modal Grammar of English: a Matter of Prolonged Fieldwork. Retrieved from http://www.cantab.net/users/michael.stubbs/articles/stubbs-1996-modal-grammar.pdf

THE SUN SAYS: Coronavirus is sure to become a deadly epidemic - how long will the advice to wash our hands suffice? (2020, March 5). The Sun. Retrieved from https://www.thesun.co.uk/news/11100999/coronavirus-epidemic-wash-hands-advice-suffice/

Tzogopoulos, G. N. (2020). Coronavirus and the Western Media. The Begin-Sadat Center for Strategic Studies. BESA Center Perspectives Paper, 1492. Retrieved from: https://besacenter.org/perspectivespapers/coronavirus-western-media/

Van Dijk, T. A. (1988). News as Discourse. Hillsdale, NJ: L. Erlbaum Associates.

Wooller, S., McDermott, N., \& Sales, D. (2020, January 23). WORLD WAR FLU. The Sun. Retrieved from https://www.thesun.co.uk/news/10799738/coronavirus-could-already-spread-uk/

World Health Organization. (2020). WHO Timeline - COVID - 19. Retrieved from https://www.who.int/news-room/detail/27-04-2020-who-timeline---covid-19 